\title{
Frode Nyeng
}

\section{Autencitet, moralsk realisme og overfladiske valg \\ - et pragmatisk blik på frihed og mening $\mathrm{i}$ Charles Taylors moralske landskab}

\section{Indledning - Taylors moralske landskab}

Vi står frit ved at være bundet. Charles Taylors opgør med den eksistentialistiske idé om radikalt frie valg er måske det, som klarest synliggør hans moralske landskab. ${ }^{1}$ Vi står først frit, når moralske krav trækker i os: Når noget eller nogen kan bede, kalde, anråbe os - med andre ord når det, vi vælger, er ladet med betydning udefra. Vore valg indstifter ikke værdierne, men svarer på dem og fører dem ind som en del af vores person. Vores frihed realiseres som valg i et landskab af forskelle, der virkelig gør forskel. Og som dermed også gør forskel for, hvilken person vi er (vort selv, vores unikke identitet). "Det var modig gjort!", "du er virkelig brutal!", "dér udviste du ægte venlighed", "din optræden manglede fuldstændig værdighed!" - ved således at vise hen til noget, som står højere end det, vi rent faktisk foretrækker, og som tilfører vore motiver bestemte kvaliteter, gør vi verden til et sted for moralsk liv og identitetsudvikling. Friheden er altså ikke primært knyttet til mængden af valgmuligheder, men til kvalitative kontraster i sproget, der åbner for det menneskelige livsrum, som vi sanser, ønsker, vurderer og handler i. I (indre og ydre) dialog om handlingers kvaliteter skabes vores eget ekspressive ståsted - vi træder frem med en egen stemme.

Sprog og realitet griber altså dybt ind $\mathrm{i}$ hinanden i dette landskab - en grundtanke, som er at finde i megen moderne filosofi. Hilary Putnam påpeger f.eks., at selv når vi ser en så enkel realitet som et træ, så er muligheden for denne perception afhængig af et helt begrebssystem, "af et gældende sprog" (Putnam 1992: 28). Når vi skal 'se', finde ud af, en så kompleks realitet som vores identitet - vores sande (men ikke givne og stabile) jeg - er vi afhængige af, at et rigt sprog af normative kontraster er 'på plads'. Ja, uden for de horisonter, som et sådant sprog giver os, er det umuligt at tale om menneskelige handlingssubjekter, hævder Taylor. ${ }^{2}$ Uden visse fælles betydningshorisonter som grundlag 
for selvfortolkning er mennesket ikke menneskeligt - uden et 'vi' intet 'jeg'. Den moralske realisme, vi stifter bekendtskab med her, henviser med andre ord ikke til værdier, som er givet uafhængigt af vores historisk betingede fortolkning. Det er snarere gennem stadig nytolkning af overleverede værdier, at vi skaber vores kollektive livsverden og vores identitet. Ja, vi må forstås som selvfortolkende og dermed foranderlige skabninger. Realismen består snarere i uomgængeligheden af visse spørgsmål end i bestemte svar og opskrifter.

I denne artikel vil hovedpointen imidlertid ikke være at gå argumenterne for en sådan moralsk realisme efter i sømmene. Målet er i højere grad at forsøge at udvikle en følsomhed over for det, jeg vil kalde det pragmatiske fundament, som en sådan filosofi efter min mening står på - noget, der indebærer, at vi støder mod grænserne til Taylors moralske ontologi. Ethvert filosofisk projekt har behov for at blive mindet om, at vore handlinger sker her og nu; bliver formet i komplekse øjeblikke, hvis mening ikke giver sig selv. Her er Taylors filosofi dybt præget af det fænomenologiske synspunkt, at vi erkender verden gennem vores praktiske engagement som kropslige skabninger - vores involverede 'coping', og ikke primært gennem neutral observation af en verden, der er objektivt givet. ${ }^{3}$ På den måde åbner hans filosofi op for megen fri meningsskabelse og selvkonstruktion. Alligevel: Er Taylors subjekt ikke tegnet lidt for robust? Har han ikke lige præcis lidt for stor tiltro til det autentiske i en verden, hvor vi stadig tvinges mere og mere til at spejle os i de andre, i en kultur, der dyrker flygtige selvfremstillinger? Har den postmoderne overfladiskhed ikke i al ubemærkethed udvisket de dybe forskelle og dermed fragmenteret selvets muligheder? Og behøver vi i det hele taget at hævde, at der findes så dybe moralske kilder for at kunne forsvare vore standpunkter, trække vore grænser og blive os selv?

\section{Sporgsmål om magt - og afmagt}

Lad os begynde med at fortælle en kort historie om moderniteten, som vi alle kender: Livet må nu leves indefra og ud. Her har vi virkelig ikke noget valg. Derfor bliver spændingsforholdet mellem det indre (selvets sandhed) og det ydre (samfundets sandheder) stærk og konsekvensrig. For vi kan ganske enkelt ikke overtage overleverede livsopskrifter. Den tid er forbi. Vores (sen)moderne tid er aftraditionaliseret. Det drejer sig ikke om, at vore forfædres normer og levemåder ikke angår os, men om at de ikke galder os: De er ikke gyldige i kraft af at være en del af traditionen. Ligeså lidt som vi kan aflæse livets sande indhold fra kosmos eller idéernes verden, kan vi leve vore forfædres liv med gyldighed. Vore liv er aftraditionaliserede i den forstand, at vi ikke længere gnidningsfrit kan indgå i en på forhånd defineret rolle. 
Dette betyder altså ikke, at vi står uden for enhver tradition og betydningshorisont. Vi står alle, hele tiden, midt i et kulturelt efterslæb af normer og tilvante synsmåder, der former os 'bag vores ryg' - dvs. for vi får foretaget egne valg - som bærer os ind i den daglige, uautentiske væremåde. Enhver person er en hermeneutisk, kulturel størrelse. Men at vore liv er aftraditionaliserede betyder, at vi midt i dette gør krav på en unik plads i og i forhold til traditionen; at vi kæmper for at gribe det nye og virkeliggøre vores eget $\mathrm{i}$ og ud fra dette kulturelle klima. Vi er traditionsbundne væsner, men vore liv er ikke traditionelle liv. Denne historie ender - som vi vel også ved, ja, mærker på kroppen - i problemer: Brændpunktet bliver, at det væsentlige ikke er at blive så lykkelig som muligt, men at forme sig selv. Men hvor, ud fra hvad? Hvordan afgøres det, hvad der er dybt, og hvad der er overfladisk? Hvem kan, og ud fra hvilken kilde, pege på det ægte $i$ alt det falske?

Selvets problem kan derfor stilles som spørgsmål om magt: Tidens dominerende imperativ er, at vi skal være os selv, men de forventninger, som vi stiller til os selv - hvordan ved vi, at de er vore egne og ikke formet af tidens hegemoniske tanker (om udtryksfuldt forbrug, om selvrealiserende arbejde, om venskab for hele livet)? Hvor langt kan vi lade de sociale processer slippe ind, før vi ikke længere har magt over os selv? Faren for at synke ned i afmagt synes således på mange måder at stige i takt med styrken i kravet om autentisk, individualiseret livsførelse. For hvordan finder vi ud af, hvem vi er, uden at blive overivrige selvrealister og opløse os selv i strømmen af forskellige individualiseringstilbud? Kapitalismen er blevet et system af massesymboler for ægthed og identitet. Så hvordan undgår vi at blive fanget $i$ den verden af små overfladiske forskelle, som den '(tids)typiske individualist' opererer i? Nej, mere foruroligende: Hvem kan længere hævde, at der findes noget, som er dybere end noget andet? For er det dybe og det forfinede ikke bare et udtryk for 'den gode smag', der tilhører de herskende klasser?

Som kunstprofessoren Siri Meyer skriver:

Magten udfolder sig ikke længere i så høj grad 'vertikalt' som 'horisontalt': Mellem et 'jeg', der er inden for og uden for sociale grupper [...] I et samfund, hvor vi skal være 'os selv', er vi afhængige af at beherske brugen af tegn og symboler, de midler kulturen, giver os for at fortælle, hvem vi er [...] De kan blive vores og formes af vore lyster og livsbegær, men de er også farlige. Vi risikerer at miste os selv i det, vi spejler os i: at blive borte i de andres blik. (Meyer 2005: 34)

Spillet om det autentiske selv er ikke risikofrit - i jagten efter det rette udtryk for ens sande jeg er det let at forsvinde i andres syn på, hvem du er, og hvad du forestiller. De stereotype forestillinger - som knyttes til alverdens mær- 
kevarer, fritidsbeskæftigelser, uddannelser, litterære foreninger, internetspil og gruppetilhørsforhold - omslutter selvets autenticitetskamp. Magtspil kan i udpræget grad dreje sig om at udfordre andres blik. Og flydende rundt $\mathrm{i}$ dette kan vi selvsagt tænke os en ekspressivitet, en 'image-fiksering', som i ringe grad har berøringspunkter med Taylors begreb om stærke værdivurderinger.

\section{Identitet og det godes dimension}

Det er selve den moderne, radikale selvrefleksion, der skaber rum for det moderne selv, hævder Taylor. Ikke forstået som det at være en neutral, uafhængig 'tilskuer til sig selv' men som det at være engageret i sig selv som kilde til sine handlinger. At være kilde, centrum og ansvarlig for sine handlinger bygger ikke på, men er det, som ligger $i$ vores individualitet og frihed. Og dette er et selvforhold, der forudsætter stærke værdivurderinger - altså at man ikke bare eller først og fremmest er målrettet $i$ betydningen resultatorienteret, og heller ikke kun orienterer sig ud fra pligter og rettigheder, men ud fra hvad der er godt og meningsfuldt i sig selv. I stærke værdivurderinger etableres følgelig højere standarder for bedømmelse af vore ønsker og valg, noget som er en uudryddelig del af det engagerede selvforhold.

Menneskets værdihorisont kan selvsagt være tavs, al den stund mennesker er præget af varierende grader af gennemsigtighed for sig selv. Ifølge Taylor har stærke vurderinger i praksis to sammenvævede sider: Den deskriptive, som fortæller, hvordan mennesket er, og den normative, som fortæller, hvad der konstituerer et autentisk selv. Den deskriptive side fortæller, at man alligevel må siges at have en værdiorientering - en fornemmelse eller moralsk intuition for det, som er højere og vigtigere end noget andet - selv om man ikke har artikuleret den, (det er dette, Taylor betegner med sit begreb om normative strukturer ${ }^{4}$ ). De stærke vurderingers normative karakter fortæller så, at ens personlighed vokser frem som mere moden, dybere og klarere som følge af en artikulation af det, vi mener er godt i sig selv.

Det vigtigste i denne forbindelse er måske Taylors opgør med enhver naturalistisk tolkning af det gode. Vi kan ikke diskreditere ethvert kvalitativt skel mellem goder, hævder Taylor, og dermed i praksis sætte lighedstegn mellem det, vi sætter pris på, og det, som er prisværdigt. Forenklet kan vi sige, at hans moralske ontologi opererer med et primært begær, der er uden det, vi vil kalde for vurdering, med sekundære vurderinger, hvor vi tænker igennem, hvad det er, vi virkelig ønsker mest (svage vurderinger), og så et tertiært niveau herover, hvor vi kan tale om vores egentlige selvbevidsthed - dvs. der, hvor vi reflekte- 
rer over, hvilken person, vi ønsker at være (stærke vurderinger) ud fra, hvad vi synes er et godt liv. Sådanne refleksioner indeholder uudryddelige kvalitative kontraster (modig - fej, sød - slem, værdig - uværdig), og de forudsætter, at noget er mere betydningsfuldt end noget andet, uafhængigt af ens personlige ønsker og interesser.

Vores værdibevidsthed strækker sig altså her ud over det, vi kan kalde for ønsketænkning - ud over det at 'ønske sig andre ønsker' (f. eks. at ønske at man ikke ønskede at ryge eller at køre bil i så høj en hastighed). Vi har ikke bare ønsker og samtidig ønsker om, hvilke ønsker vi vil have. Vi er også optaget af ønskernes onskvardighed. Og kun på denne måde former man ifølge Taylor sin egentlige vilje. Dermed kan vi sige: Vil du noget, så ønsker du det også, men ønsker du noget, behøver du egentlig ikke at ville det. Jeg kan fx afstå fra at handle med aktier, selv om jeg ønsker et bedre afkast af mine sparepenge. Ikke fordi det kræver tid og ressourcer, men fordi jeg moralsk set ikke vil være en person, som bedriver den slags aktivitet. Jeg afstår altså af den grund, at aktiehandel er motivmassigt uforeneligt med det, jeg mener er godt, og ikke bare fordi det er praktisk uforeneligt med mine andre ønskelige gøremål. Der er desuden intet 'naturligt' eller selvfølgeligt i det at bedrive nytte- og fortjenestemaksimering. Og inden for rammerne af en naturaliseret nyttetankegang kan man slet ikke svare på, bvorfor dette skulle være vigtigt, eftersom nytte(etisk)-tænkning ikke giver plads til stærke vurderinger og værdimæssige begrundelser. Det sidste er en pointe, som også rummer Taylors grundlæggende kritik af utilitarismen: Utilitarismen er ude af stand til at gøre rede for sit eget normative grundlag. ${ }^{5}$

På den ene side har vi derfor den menneske- og rationalitetsforståelse, der er bygget op omkring målrettethed, forstået som en bevidsthed om det subjektivt set bedst mulige udfald i forhold til givne mål. Dette er en menneskeontologi, som har præget megen samfundsvidenskab, særligt økonomi, i form af såkaldt 'rational-choice'-teori. På den anden side har vi altså den taylorianske forståelse, hvor mål er udtryk for, at bestemte handlinger vurderes som værende af inkommensurabel højere værdi end andre. Taylors moralske realisme rummer altså det godes dimension i direkte opposition til dominerende moderne etisk teori, der, som Taylor skriver, har fokuseret:

på principperne, påbudene eller standarderne, som styrer handling, mens visioner om det gode fuldstændigt negligeres. Moralitet beskæftiger sig snævert med, hvad vi burde gore, og ikke også med det, der har værdi i sig selv, eller med det, vi burde beundre og elske. (Taylor 1989: 84) 
Det er altså her, vi finder kilden til en ikke-triviel identitetskonstruktion. Vi kan kun definere os selv i forhold til noget af betydning, noget vi meningsfuldt kan elske eller beundre, og dette 'af betydning' berører de tre aspekter: respekt. for andres liv, forståelse af, hvad der gør livet meningsfuldt, og vardigheden i vores omgang med os selv og andre. Dette afspejler vore tre mest grundlæggende moralske intuitioner, hævder Taylor. Man kan som bekendt ikke definere sig selv - noget Taylor selv bruger som eksempel - ud fra, at man er det eneste menneske med 3732 hår på hovedet eller er den eneste, som er nøjagtig lige lang som et bestemt fyrretræ i Sibirien (Taylor 1989: 48). Uafhængigt af det enkelte subjekt må der findes standarder, der giver os det, vi kan kalde for genkendelige selvdefinitioner, og som giver vores sjæl indre dybde.

Derfor er det at have identitet koblet til moralske fordringer i kraft af, at dette indebærer at have forpligtende forestillinger om det gode liv. "Hvilket liv er værd at leve?", "hvad udgør en meningsfuld tilværelse?", "hvad tilfører mit liv værdighed?" - dette er en type spørgsmål, som ikke er valgbare ("not an optional matter"), ifølge Taylor. ${ }^{6}$ Dermed er identitet ikke det empiriske begreb, som mange samfundsforskere vil have det til at være. For at have en fornemmelse af, hvem vi er, er vi nødt til at have en forestilling om, hvor vi står, og hvor vi er på vej hen i det landskab, der former sig ud fra vore fælles betydningshorisonter. Det, Taylor her bidrager til, er en indholdsrig påpegning af, at vi ikke kan skabe os selv ud fra intet, men at selve spørgsmålet om, hvem vi er, forudsætter at vi kan bestemme os ud fra et genkendeligt ståsted og en nødvendig livsorientering. Han klargør, at individualiseringsprocesser er uløseligt knyttet til værdispørgsmål og han viser således, at identitet er et normativt begreb. Det normative begreb om personlig identitet bryder derfor klart med sociologisk og psykologisk teori, hvor identitet er ensbetydende med tilskrevne forventninger eller med den faktiske anerkendelse, vi modtager fra andre.

Uanset kulturelt klima kan vi selvsagt afstå fra at forholde os bevidst og refleksivt til vore mål og værdier. Men hvis vi konsekvent afstår fra dette, lader vi i realiteten vore handlinger blive bestemt af vaner og etablerede værdiopfattelser. Ved simpelthen at kunne lide det, vi kan lide, mene det, vi mener, og foretrække det, vi foretrækker, frasiger vi os vores positive frihed - at vi kan være vore handlingers kilde. Dette er en erkendelse, man kan tilslutte sig også fra et rent pragmatisk ståsted: At stå uden en særlig refleksion over alternative livsveje er at frasige sig sin menneskelighed - at lukke døren for at kunne bidrage til at raffinere og udvide mulighederne for kreativ livsudfoldelse. Stivnet eller fraværende argumentation for, hvad der er godt, repræsenterer en lidet skabende og tilpasningsdygtig personlighed, en indsnævring snarere end en udvidelse af ens livsmuligheder. Det filosofisk set problematiske opstår, når 
en sådan pragmatisk begrundelse for værdirefleksion møder Taylors absolutte, praksisuafhængige forankring for det gode.

\section{Positiv fribed behover forankring - men $i$ bvilken form?}

Individualisering sker gennem det almene. Vi læser vore virkelige udfordringer i kulturens sprog. Og man kan da heller ikke have nogen oplevelse af sin identitet, før man har behov for en - dvs., som blandt andre Zygmunt Bauman præcist har påpeget (Bauman 1996a; 1996b), før man er kastet ud i en kulturel tilstand, hvor man kan mangle eller være usikker på sit ståsted og sit tilhørsforhold. Det er først, når man befinder sig i en tilstand af valg og flere muligheder - og man føler både et behov og et pres for at vælge ud fra sig selv - at man kan undres over, hvem man egentlig er. Det er netop denne tvetydige tilstand, der åbner for den usikre balancegang mellem magt og afmagt, som jeg skitserede tidligere.

Men der er selvsagt forskel på at hævde, at en rigtig beskrivelse af det moralske liv må anerkende den funktion, som vores erfaring af højere, transsubjektive kilder til det gode spiller i praksis, og så at hævde, at der findes moralske kilder uafhængigt af mennesket. Vi må her huske på, at en essentiel del af Taylors realisme er udlagt som moralsk ontologi, hvor de moralske kilder ligger dybere end vore artikulerede værdier. De moralske kilder tilhører vores dybeste menneskelighed og kan heller ikke gøres fuldt ud transparente. Vore ord berører kilderne og kan derfor have enorm moralsk kraft, men de udtømmer dem ikke. Dette kan for så vidt siges at følge af en højst dennesidig hermeneutik, (alt ved vores situation kan ikke ekspliciteres samtidig; enhver forgrund må have en baggrund). Men hos Taylor er etikken og grundlaget for de stærke vurderinger hverken reducerbare til subjektivitet eller intersubjektivitet. Taylors filosofiske kamp mod fragmentering af både selvet og fællesskabet sker på baggrund af tro på en 'basic moral source', der transcenderer det (mellem)menneskelige.

Hvad så med os, der ikke tror på hverken en teistisk Gud eller noget andet absolut værende, der overskrider vores identitet og meningsskabelse i praksis - som mangler tro på en transcendent kilde til det gode forud for det menneskelige? Ja, vi kan, som påpeget, være overbeviste om, at Taylor indfanger noget væsentligt med sin beskrivelse af det gode som uudryddeligt fra etikken og med sit begreb om stærke vurderinger som uomgængelige for identitet og menneskelighed. For det er tydeligvis, som Taylor påpeger: "Selv-valg giver mening som ideal, hvis blot nogle spørgsmål er vigtigere end andre." (Taylor 1998: 52). Kan vi så samtidig tillade os at holde os inden for intersubjektivite- 
ten og i solidaritet udkampe en praktisk kamp for en forståelse af autenticitet som forhøjet selvbevidsthed? Med andre ord: Kan en sådan kamp ikke vokse frem uden tilførsel af energi fra noget hinsides det menneskelige?

Autenticitet må i så fald ikke forstås som troskab mod værdier eller som realiseringen af et 'helstøbt' selv, men snarere som en genuin tilstedeværelse i ens situation og indforståethed med det konstruktive element $i$ al meningsskabelse. Det handler om at være bevidst om det, der vokser frem - ikke om at orientere sig ud fra det, der er systematisk givet. For pragmatisk set kan en filosofisk realisme lige så lidt binde sig til et syn på noget absolut godt og vigtigt som til det syn, at verden består af en bestemt mængde tanke- og påstandsuafhængige objekter. Samtidig har vi åbenbart behov for at kunne sige, at tingene er 'derude', at vi møder dem, forpligtes og bærer dem videre. Om end altid i en lidt forandret, nyforhandlet form. Og jeg mener langt hen ad vejen, at vi ikke kan finde nogen bedre formulering af en troværdig - lad os kalde det en pragmatisk realisme - end i Taylors eget credo om, at "what is real is what you have to deal with". ' Som opgør med et naturvidenskabeligt syn på mennesket og som en genopdagelse af vores virkelighed som en meningsladet handlingsarena, fungerer det da også aldeles udmærket.

Som Simon Blackburn understreger i sin sidste bog Truth, sker der imidlertid ofte en uheldig tingsliggørelse af værdier, fordi vi synes at have brug for et sprog for det ikke at være grænseløse skabninger:

Moralisten kan måske antage, at han tror på menneskerettigheder, fordi menneskerettigheder eksisterer, og fordi han lader sig påvirke af dem. Men fra sidelinien kan kritikeren, (som måske holder lige så meget af menneskerettighederne), fortælle en anden historie, hvorved den indstilling til menneskelivet, der kommer til udtryk i denne slags formuleringer, gives en anden og mere tilfredsstillende forklaring. Det forholder sig f.eks. ikke sådan, at vi modtager information om rettigheder på akkurat samme måde, som vi modtager information om træer eller buske, men i stedet sådan, at vi forsøger at konstruere og insistere på grænser for handlemåder, og dette gør vi i sproget. (Blackburn 2005: 21)

Selv er Blackburn ikke blandt dem, der siger god for et sådant 'funktionalistisk' moralopgør, men udsagnet skitserer en kritisk, pragmatisk ramme for at forstå det objektive værdisprog, som jeg finder stadig mere tiltalende i mødet med Taylors tunge moralforankring.

Der er selvsagt en grundlæggende wittgensteiniansk tanke i dette, som det må siges, at også Taylor langt hen ad vejen deler. John Shotter tolker denne tanke et skridt længere i praksisnær retning, når han siger: 
Det, som bliver centralt [...] er ganske enkelt vores kropslige 'leven-hed', vore levende relationer med vore omgivelser. I stedet for tanker og idéer skjult inde i vore hoveder vil det centrale fokus for vore undersøgelser blive de spontant udtrykte, levende, modtagelige og relationelle aktiviteter, der foregår mellem os ude i verden, hvor alle kan se dem. (Shotter 2005: 114)

Pragmatisk forstås kundskab netop som handlingsberedskab. At vide er ikke at besidde sande påstande $i$ et indre, mentalt rum, men er knyttet til det at klare sig selv, ordne virkeligheden, inklusive det at udtrykke sin værdiforståelse, forvalte og forny sine interesser i lyset af moralske idealer. Kundskab kan ikke forstås intellektuelt, men må forstås praktisk og kropsliggjort, som evner vi har udviklet nedsunket $\mathrm{i}(\mathrm{sam})$ handlingskrævende situationer. Vi må altså spørge, om ikke også vores kundskab om værdimæssige grænser kan forstås som dele af en sådan praktisk kundskabstilegnelse med al mulig 'forankring' i vore behov for at indrette, påvirke og forme vore omgivelser ud fra vores livsbegær og vore foranderlige interesser.

Samtidig er vi som mennesker ikke fuldstændigt beskrevet som subjekter i bevidste refleksions- og handlingsprocesser. At være menneske er også at være styret, ledet af ubevidste - men ikke nødvendigvis fortrængte - motiver og processer. Marcia Cavell siger som udgangspunkt for sin udforskning af psykoanalysens grænser til filosofien:

Jeg fastholder, at enhver diskussion om, hvad det indebærer at være et menneskeligt 'selv' eller 'subjekt', må insistere på fire idéer, der er centrale i psykoanalysen: For det første at mange mentale funktioner er ubevidste [...]; for det andet at hukommelse antager forskellige former, som bærer forskellige grader af bevidsthed med sig, for det tredje at graden af bevidsthed ofte er dikteret af ubevidste forsvarsprocesser, som bringes i spil mod smerte og angst, og endelig at fortiden ofte informerer nutiden på måder, som vi ikke er bevidste om, og som vi mangler direkte kontrol over. (Cavell 2006: 2)

Vi skal ikke gå ind i dette store alternative landskab her. Men dette udsagn giver os - selv blot på overfladen - endnu en frugtbar indgang til en selvets pragmatik.

\section{Meningens dobbelthed}

For dette gør det muligt at se meningsskabelse i alle dens former, der svarer til følt kompleksitet, kort sagt: til angst. Noget, som giver fænomenet mening 
- og særligt mening forstået som narrativ livsmening og selvidentitet - en dobbelt, tvetydig karakter. Set i lyset af et pragmatisk-eksistentielt autenticitetsideal er det ikke bare den implicitte baggrund, vi har arvet og er født ind i, men også vore aktive selvfortolkninger, der kan bedømmes som inautentiske - hvis de bliver 'for realistiske', dvs. for systemiske. Ud fra en sådan tilgang til mening kan fragmentering og fremmedgørelse ligeså vel skyldes konkurrerende forsøg på at definere den sande kilde, det rette tankesystem, som en opløsning af værdifællesskab ud fra en kollektiv fremdyrkelse af instrumentelle og narcissistiske grundholdninger, (hvilket er den dominerende taylorianske forklaring ${ }^{8}$ ).

Vi står altid-allerede $i$ verden som meningsladet. Det betyder, at vi uundgåeligt møder vore praktiske problemer som problemer af en bestemt type. Vi får straks kastet løsningerne på os. Det handler om iværksættelse af det, vi ved skal til; det, som giver god mening, der svarer til situationen. Mening fremstår klarest, når verden er færdigindrettet. Mening er generelt noget stivnet, der låser os fast $\mathrm{i}$ et systemmæssigt, institutionaliseret forhold til verden - en meningsladet virkelighed er et resultat af vore behov for orden, kontrol og forudsigelighed. Den filosofiske klargørelse består her i, at det synliggøres, hvilken dobbelthed, der præger en sådan meningsladet virkelighed - den klargør for handling, får os til at føle os hjemme i verden, så den opleves god og tryg. Men samtidig: Mening vil altid være løgn, eftersom øjeblikket altid er forsvundet, verden er gået videre - den i bevægelse, du igen bevæget. Sådan kan livet troværdigt beskrives som en serie (sammen)brud, og mening kan beskrives som en altid forsvindende tentativ orden - mening er altid noget, der har fungeret. Identitet er altid noget, vi har været, ligesom steder altid er noget, vi har besøgt og forladt. Pragmatisk set er øjeblikket indeklemt mellem (fortidig) mening og (fremtidig) meningstomhed.

Så hvem er jeg? Det filosofiske svar kan først komme som et pragmatisk opråb: Glem essensen, glem endeligheden og den absolutte forankring - den form for sikkerhed står aldrig på spil. Dette er selvsagt igen wittgensteiniansk: Hvis tvivlen rettes mod billeder, der ligger ved roden af vores tænkning, så bør man revurdere tvivlen snarere end den rodfæstede tænkning. Som et nyforelsket par, hvor den ene pludselig spørger "Hvad er det egentlig, vi har gang i?". Der spørges efter, hvad konsekvenserne sandsynligvis bliver, hvilke handlinger forelskelsen ansporer til, og ikke efter forelskelsens sande, skjulte essens. "Hvad sker der, hvis jeg skal præsentere dig for min familie?...", "kommer jeg nu til at miste min tidligere kæreste som min bedste ven?...". Sådan kan vi også mere generelt se det at spørge: "Hvad er det egentlig, vi har foran os her?" som et spørgsmål om, hvad konsekvenserne vil blive, såfremt det, man har foran sig, indgår i forbindelser med andre ting af betydning i ens liv. "Hvem 
er jeg, som tillader mig at forelske mig på denne måde?” - identitet er uløseligt knyttet til kontekst. At spørge efter det absolutte er at overse konteksten, hvor problemet opstår; enhver flydende sammenhæng, hvor sådanne spørgsmål i praksis tvinger sig frem.

Der er altid konkret (sprog)handling knyttet til selvet. Selvet er indfanget i sin egen praksis. For at fremstille denne pointe så klart som muligt kan vi nærmest anekdotisk betragtet her medtage, hvorledes Jon Hellesnes viser dette: "Hvis en person $i$ alle slags sammenhænge beretter om sit underlæggende sjæleliv, så må vi sige, at det karakteristiske ved ham er, at han taler om sit underlæggende sjæleliv.” (Hellesnes 2202: 35). Vi kan aldrig selv få det hele med i billedet - den endelige afgrænsning af jeget er forbeholdt de andre. Så på en måde er identitet noget, vi uundgåeligt har derved, at vi altid forstår os selv som noget bestemt. Men på en anden måde er det noget, vi kæmper for og følgelig kan mislykkes $i$ at opnå, mislykkes $i$ at holde fast ved og altid vil mislykkes $i$ at afgrænse. Ikke mindst på grund af det dialogiske samspils uoverskuelige og ukontrollerbare logik. Få ting er så komplekse - og risikofyldte - som de konkrete møder. At forstå - være-i - et konkret møde ud fra noget 'færdigt', på en stivnet baggrund, gør os uundgåeligt mindre og ikke større.

Det, jeg har forsøgt at drage frem her, er relativt ukompliceret: I hverdagslivets konkrete sammenhæng vil al erfaring af forandring og sammenbrud selvsagt være forbundet med en normalforståelse af konstans, struktur og forventning om komfortabel bevægelse - og følgelig være en smertefuld trussel om meningstab. Forandring er brud med forventninger om tings videreførelse som sig selv. Men i det pragmatisk-filosofiske blik er forandring det, som fylder billedet, og meningsskabelse er den nødvendige flugt fra angst og forandringens konstans. I et sådant billede bliver autenticitet modstykket til selvidentitet og værdiers fasthed, et billede, hvor vi ikke kan finde et klarere, renere eller mere entydigt grundlag for mening end (selvfortolkede) menneskelige behov og interesser. Dette leder os direkte ind i kærnen af nypragmatisk filosofi.

\section{Nypragmatisk liberalisme}

En af de mest centrale nypragmatiske filosoffer er amerikaneren Richard Rorty, som også er en af Taylors væsentlige kritikere. Og Rortys eget liberale imperativ - som han opsummerer i det slagordsagtige "don't be cruel" - har normativ kraft; ikke ved at reflektere noget filosofisk sandt - indsigt i menneskenaturen - men ved at binde os til en tradition, hvor det at værne andre mod onde handlinger og grusomhed har den største værdi. Som Rorty for nylig udtalte i et interview: 
Men Platon tog fejl. Det findes ingen førsteprincipper. Du ser dig omkring, du læser historie, og du ender med at få visse fornemmelser for, hvad der er vigtigt, og hvad der ikke er det. Så konstaterer du noget, f.eks. at onde handlinger er det værste, vi gør. Dette er bare et slagord, som opsummerer din reaktion på, hvad du har erfaret eller læst. ${ }^{9}$

Det er konkrete historier om grusomhed, der skal få folk til at mene det samme som os - etisk teori klarer ikke sagen.

Spørgsmål som "hvordan afgør du, hvornår du skal kæmpe for social retfærdighed, og hvornår du skal hengive dig til private sysler?", "er det rigtigt at ofre to uskyldige for at redde fire andre?" og "hvornår kan man favorisere sine egne frem for fuldstændigt fremmede?" har ikke principielle svar. Enhver, som tror, at der findes velbegrundede teoretiske svar på sådanne spørgsmål, svæver i metafysisk vildfarelse. Alt vi kan gøre er at lytte til forskellige historier - fra litteratur, medier, kunst, filosofi og hverdagsliv - og danne vores egen mening inden for den værdihorisont og i det sprog, vi forvalter. Vore kilder til moralsk handling er praksisnære konventioner, anekdoter og fortællinger. Der er selvsagt et historisk element i dette, som forklarer Rortys begrænsede tro på filosofisk teori. Tiden for teoretisering er for længst overstået ifølge Rorty - problemet er nu ikke længere filosofisk, men praktisk, og handler om motivation og implementering. Motivation for den praktiske kamp mod social uretfærdighed, diskriminering, fattigdom og manglende retsbeskyttelse af individet og for implementering af liberale institutioner, der kan forvalte - sådan som det blev formuleret allerede af John Stuart Mill - den rette balance mellem beskyttelse af privatliv og det at forhindre ondskab og lidelse.

Mennesket har værdighed, ikke i kraft af at realisere en plan eller evner nedfældet i dets ene, sande natur, men ved aktivt at gå ind for - og være villig til at forsvare - konkrete sider ved ens samfund og tradition. Det centrale i Rortys pragmatisme er derfor opfordringen til et konkret forsvar for det liberale, demokratiske samfund og velfærdssystem. I dette ligger en handlingskrævende bevidsthed om det historisk kontingente - og dermed det usikre og sårbare - ved vores egen ligeværdsorienterede civilisation. En erkendelse af, at fremkomsten af liberale demokratier i den vestlige verden er en historisk tilfældighed og ikke en logisk udvikling langs en fast rationalitetsakse. Og dette vitaliserer vores egen moralske handlingsstatus ifølge Rorty. Det findes, som Bernstein pointerer, "ingen historisk nødvendighed, ingen skæbne, ingen varig menneskelig essens, der sikrer, at det demokratiske samfunds frihed vil sejre." (Bernstein 2003: 134). 
Normative standarder mister ikke nødvendigvis kraft ved, at vi indser, at de ikke er absolutte; at de ikke er hævet over den menneskelige bevægelse, vi selv er underlagt, men snarere er en integreret del af den. De forandringer, brud og kriser, vi taler om, optræder netop som vore forandringer, brud og kriser, når vi klarest ser idealerne - indholdet $\mathrm{i}$ de stærke værdivurderinger - som en del af vores evne til at se mulige alternativer, forestille os forandring og føle kompleksiteten i vore konkrete situationer. Og dermed til at kæmpe for det, vi opfatter som godt her og nu uden metafysisk sikring, uden den forkrøblede selvforståelse, som troen på et guddommelig, objektivt facit bringer med sig.

Med autenticitet gælder det om at undgå fejlen med at efterspørge selvidentitet og livsmening direkte og i stedet gøre sig indforstået med, at enhver livsmening har en nødvendig praktisk konkretisering. I et meningsskabelsesperspektiv som dette vil eksistentialiteten - begæret og livslysten, som vi så Meyer betragte som magtspillenes grundlag - ikke være knyttet til det yderste mål i kæden af meningsgivende formål, men til den refleksive bevidsthed om for altid at være undervejs i disse menneskeskabte idealers rige. Refleksionen, der ligger i vore stærke vurderinger, skal drive os ud af vore rutiner, ud af den almindelige hverdagstænkning. Skal de kunne bevirke sådanne brud, må de følgelig have en klar forankring i praksis - i det liv vi faktisk lever - uafhangigt af, om vi slutter os til overmenneskelige idealer.

\section{En dybere inautenticitet? - kritike.en af det overfladiske}

Den pragmatiske tolkning af autentisk liv indrammer det billede, at vi konstruerer og opretholder værdier i praksis og ikke opdager dem som sandheder ud fra en privilegeret indsigt. Lad os konkretisere med et nedslag i det typisk postmoderne: I romanen How to lose Friends and Alienate People af Toby Young finder vi en herlig beskrivelse af inautenticitet. Han gør sine betragtninger om det inautentiske projekt ved at 'opdage' modestrømninger set fra redaktionen i det hippe New York magasin Vanity Fair udgivet af selskabet Condé Nast:

Hvordan vidste de, hvad der ville være in i næste sæson? I deres egne øjne var det deres følsomhed over for modens omskiftelighed, deres tidsåndsradar, som kvalificerede dem til jobbet [...] Det er bare fordi trendjægerne i Condé Nast anses for at have fingeren på pulsen, at Condé Nast-magasiner bliver læst af 75 millioner amerikanere hver måned. Men jeg antog, at bag de lukkede døre, beskyttet i sine hjørnekontorer, ville glamourguerillaen indrømme, at det hele var et stort bedrag [...] jeg tog fejl. Jeg havde tillagt condénastierne alt for megen selvbevidsthed [...] de tænker hellere på sig selv 
som trendspottere end som trendskabere [...] Selvfølgelig er denne proces langt fra så objektiv, som de vil have den til at fremstå. Objektivt set skabes trends af mennesker, der optræder på en særegen måde; men for at dette kan ske, må de tænke på sig selv som folk, der forudser trends eller følger trends, der allerede eksisterer. ${ }^{10}$

Og han opsummerer på en måde, som selvsagt får os til at løsne sikringen på vores taylorianske pistol:

Ved at gå klædt i sidste nye skrig, nynne til de nyeste melodier og spise på de hotteste restauranter, tror de, at de er i kontakt med noget betydningsfuldt og dybt. I deres øjne refererer 'det' i udtrykket "dér, det sker" til en mystisk, uhåndgribelig eksistens, som har mange af de samme egenskaber som en guddommelig skabning. Det er usynligt, men alligevel allestedsnærværende; det er i denne verden, men alligevel ikke helt af den [...] Kort sagt er det et ekko af Guds vilje.

Det, som tegner sig, er i hvert fald et meget præcist billede af, at praksis ofte er selvforsynet med energi, så længe man forestiller sig, at praksis bygger på noget praksisuafhængigt. Hvad er inautenticiteten så knyttet til?

Dette er åbenbart inautentisk, fordi disse smækre trendspottere ikke evner at se deres egen aktive rolle i konstruktionen af de trends, de er så besatte af. Men pistolen er nu ladt, og med Taylor må vi indrømme en fristelse til at sige noget langt mere substantielt. Vi må sige, at ligegyldigt hvad, så foretager de sig noget, der aldrig kan tilføre mennesket en autentisk identitet, idet de forskelle, som de dyrker, er overfladiske og ikke har at gøre med ægte, identitetssensitive spørgsmål. Problemerne, de løser, og situationerne, de opererer i, berører i beskeden grad de menneskelige kapaciteter, som ligger til grund for en positiv frihedsudfoldelse. Den materialisme og de kødelige glæder, der dyrkes, afspejler følgelig ingen værdispørgsmål, som kan uddybe og nuancere deres syn på gode mål. Kontrasten mellem en Chanel og en Burberry taske svarer på ingen måde til nogen væsentlige kvalitative aspekter. Det er ikke muligt at sige, at de repræsenterer nogen grænsedragning eller handlingsstandard med normativ kraft. Og den, som først og fremmest er lidenskabeligt optaget af interiørdesign, (her kan man bare opremse alverdens temaer fra forbrugerkulturen), må siges at have bundet sine stærke følelser til et snævert felt af muligheder.

Den tidstypiske betydning af mundheldet 'vi lever i tiden' kommer direkte i denne skudlinie. Vi er i sandhed i tiden ved at italesætte os selv, skabe narrativer, skabe sammenhæng - ved at vi uundgåeligt ser vores liv udfolde sig i tråd med fornemmelser for de gode og væsentlige værdier, vi kan forsvare med argumenter som værende væsentlige. "Min fornemmelse af mig selv er en for- 
nemmelse af et væsen, der vokser og bliver til", skriver Taylor (Taylor 1989: 50). Hvis ikke vi oplever, at livet har sammenhæng, hvis dagene bare følger hinanden som fragmenter, uden retning, som i en døs, uanset hvor trendy det måtte være... For Taylor betyder dette, at tiden så at sige opløser sig mellem hænderne på os og forsvinder i mørk intethed - tiden er både tabt og bortkastet; den passerer bare, som om vi ikke har været en del af den. ${ }^{11}$

I min bog om Taylors filosofi skrev jeg for nogle år siden, at "få perspektiver på menneskets handlingsliv sætter det individuelle liv så stærkt i centrum som et forbrugerperspektiv. Forbrugerrollen er ganske enkelt manifestationen af det genuint selvcentrerede individ." (Nyeng 2000: 232). Og selvcentreret selvrealisering er netop, hvad Taylor advarer mod i sin påpegning af det, han mener, er glidebanen mod tidens subjektivisme. Nu er det langt fra sikkert, at der kan foretages en sådan entydig kobling mellem forbrug og overfladiskhed og en tilhørende triviel meningsskabelse. ${ }^{12}$ Men det pragmatisk-filosofiske spørgsmål er her: Behøver vi Taylors grove ammunition for at ramme det forbrug, der er støbt i hule og trivielle selvrealiseringsformer, som dyrker øjeblikket på bekostning af tiden?

Hvis vi virkelig eri en postmoderne tilstand, så bliver spørgsmålet selvsagt, om vi holder ud. For som civilisationskritikeren Zygmunt Bauman minder os om:

Postmodernitet er punktet, hvor den moderne opløsning af identiteter når sin fuldstændiggørelse: Det er nu alt for let at vælge identitet, men ikke lettere at holde fast på den. I det øjeblik frigørelsen når sin triumf, tilintetgør den målet. Jo friere valget er, desto mindre opleves det som et valg. Valget mangler vægt og soliditet [...] Friheden slår tilbage som vilkårlighed. ${ }^{13}$

At leve udelukkende gennem valg, der aldrig anses som endelige og forpligtende, men som principielt tentative, 'lette' og reversible, kan selvsagt kritiseres, også ud fra det skitserede pragmatiske autenticitetsideal. At lukke sig inde i sig selv og sit eget - at kappe forbindelser for at blive 'helt fri' - betyder ikke andet end at miste muligheder for vækst og udfoldelse.

Vægten og soliditeten behøver ikke at stamme fra noget super-menneskeligt. Det er tilstrækkeligt, at vi husker hinanden på, at det uundgåeligt er ens fortolkede fortid og fremtid, der gør det meningsfuldt at tale om nutid, om øjeblikket. Vores evne til narrativ, normativ selvforståelse er umulig at se bort fra, også hvis man forstår den helt igennem dennesidigt. Her-og-nu kan ingen egentlig vare, som ikke helt kan orientere sig ud fra den forståelse, at noget er mere betydningsfuldt end andet. Taylor formulerer også dette glimrende selv, når han påpeger, at 
i den grad folk søger et moralsk ideal her, er denne indelukkethed af selvet fordummende, den ødelægger betingelserne for, at idealet kan blive virkeliggjort [...] Autenticiteten er ikke fjendtlig indstillet over for krav, som har deres oprindelse hinsides selvet; den forudsætter sådanne krav. (Taylor 1998: 53)

Hvorvidt mennesket så kan lide sig selv tilhører ikke filosofien - ikke på anden måde, kunne vi pragmatisk set sige, end at dette tydeligt viser, at kun den, som betragter sig som fri, er fri.

\section{Afslutning - ved filosofiens grcense}

Den rigtige måde at bedrive filosofi på er at bidrage til, at man kan forlade filosofien og få noget gjort - at man gennem klargørelse bringes ud af filosofien og tilbage i en livsbekræftende praksis. For det forholder sig ikke sådan, at vores mangfoldige praksis har behov for filosofisk begrundelse eller for et solidt filosofisk fundament - filosofien kommer ikke først. Og den kommer heller ikke sidst.

Filosofien opstår omvendt ud af praksis, som en begrebsmæssig forvirring, hvor man - for at sige det med Wittgenstein - glemmer de konkrete kontekster og begynder at søge efter sprogdelenes absolutte brugsuafhængige mening og forankring. Spørgsmål som "hvordan opstår viden om den ydre verden?" er af samme type som spørgsmålet "hvordan opstår et samfund?". Begge indebærer, at man glemmer følgende: Det er kun i helt særlige tilfælde, at vi har behov for at forklare grundtræk ved mennesket og dets verdensforhold. Det samme vil kunne siges om spørgsmålet "hvad er et selv?" eller "hvordan bliver selvet til?". Når spørgsmål om identitet, frihed og meningsskabelse fjernes fra praksis og abstraheres til filosofisk refleksion, så bliver meningen - altså muligheden for svar - uklar. Det er, kunne man sige, det modsatte af, hvad Taylor synes at ville fortælle ${ }^{14}$ : Vores rodede, beskidte praksis; vores daglige mylder af forskelle, forhandlinger og magtspil, tildækker ikke de moralske kilder og gør dem utilgængelige for artikulation - det er her, de bliver til, holdes oppe, og her vi følger dem.

Pragmatisme - sådan som jeg har beskrevet det her - er samtidig uforenelig med relativisme og postmoderne lige-gyldighed. Etiske problemer kan tjene som eksempler, hvor det ofte er netop en praktisk umulighed at blive enige om at være uenige; at acceptere forskellige opfattelser. Sagt på en anden måde: At acceptere forskellighed kan ikke betyde at sidestille forskellige positioner og opfattelser og erkende dem som 'lige gode' ud fra den opfattelse, at der ikke findes noget overordnet standpunkt. At acceptere en meningsmodstanders opfattelse i etiske spørgsmål vil svare til at acceptere realiseringen af en 
anden praktisk virkelighed end den, man mener, er den rigtige. Det svarer til at ophæve sine egne grænser. Samtidig trakker man en grænse og indtager et standpunkt - man opdager ikke grænsen for dernæst at lade den diktere, hvor vi står. At dette sker kontekstuelt er ikke et svigt eller en begrænsning i den gyldighed, som vi mener, ligger i vores standpunkt. Det er snarere en central del af vores begreb om at mene og stå for noget. Som handlingssubjekt, som aktivt meningsskabende, kan vi ikke betragte det på den måde, at det, vi selv mener, er et rent produkt af vores baggrund, vores klasses smag, racetilhørsforhold eller 'tilfældige' historiske indplacering. Men vi kan uden inkonsistens erkende dette som formende kræfter, samtidig med at vi står ved det, vi mener. Hvad der gør, at en etisk overbevisning er gyldig, kan ikke forstås uden dette, at vi faktisk behover konkret at trække en grænse for værdighed i forskellige situationer ud fra os selv.

Men pragmatisk fortolket er stærke værdier også arbejdshypoteser, som vi organiserer vore liv efter - de er ikke faste idealer eller absolutte grænser. Det er antageligt her, mit pragmatiske sindelag tvinger mig til at træede ud af den taylorianske realismens filosofiske landskab. For jeg har svært ved at se, at Taylor helt kan acceptere den åbenhed, som ligger i en gennemført pragmatisk holdning til værdibegrebet, sådan som f.eks. Erik Lundestad klart formulerer det:

Det, vi er afhængige af for at være moralsk ansvarlige, er [...] ikke en god vilje eller en evne til at anvende et abstrakt princip på konkrete situationer. Det, som vi behøver, er snarere at udvikle evnen til at forestille os forskellige muligheder samt at være åbne over for den rigdom, den mangfoldighed og den kompleksitet, der præger vore liv [...] Vi kan ikke give prioritet til en enkelt værdi, og det er heller ikke muligt at ordne vore forskellige værdier $i$ et hierarki. Vi må snarere leve med konsekvenserne af, at vore handlinger udføres $i$ konkrete situationer og op imod en baggrund af stadig forandring. (Lundestad (upubl.) 2006)

Det er i en sådan følt virkelighed, at jeg læser Taylor og finder ham interessant og udfordrende. Men jeg behøver ikke hans form for realisme fuldt ud - jeg har blot brug for at vide, som Simon Blackburn siger, at det af og til er "tid til at trække en grænse og tage et standpunkt, og at alternative måder at se ting på kan være korrupte, ignorante, overtroiske, prægede af ønsketænkning, langt ude eller simpelthen onde." (Blackburn 2005: 66). Der står man - og så er man dømt til at tage det hele derfra, i ydmyghed og venlighed, som Bjørn Ramberg siger: med "tiltro og tillid til vore idealer, uden absolutisme og uden underkastelse."'15 


\section{Noter}

${ }^{1}$ Se særligt artiklen "What is human agency?" (trykt i Taylor 1985b, især s. 29$35)$.

${ }^{2}$ Se f.eks. Taylor 1989: 27.

${ }^{3}$ En god beskrivelse af dette findes i Smith 2004.

${ }^{4}$ Begrebet om et (tavst) betydningsfelt ('framework') for vurdering af livsmening og handling er centralt helt fra begyndelsen i Taylors hovedværk Sources of the Self. Se Taylor 1989: 16-20.

${ }^{5}$ Se Taylor 1989, særligt s. 22-24 og s. 82-87.

${ }^{6}$ Se f.eks. Taylor 1989: 42.

${ }^{7}$ Se Taylor 1989: 59.

${ }^{8}$ Se Taylor 1998, særligt kapitel 5.

${ }^{9}$ Rorty i et interview i avisen Morgenbladet d. 7.oktober 2005 under overskriften "Pragmatisk sosialdemokrat".

${ }^{10}$ Young (gengivet efter den norske oversættelse) 2006: 205-207.

${ }^{11}$ Se Taylor 1989: 44-46.

${ }^{12}$ I bogen Forbruk (Blindheim/Jensen/Nyeng/Tangen 2004) har jeg som en del af et tværfagligt projekt blandt andet været med til at udforske og udfordre den moralske forbrugerkritik.

${ }^{13}$ Bauman gengivet i Svendsen 1999: 80.

${ }^{14}$ Se Taylor 1989, særligt s. 91-97, og Connolly 2004 for kommentar og diskussion.

${ }^{15}$ Ramberg i et interview om Rortys pragmatisme i litteraturtidsskriftet Boygen (ved Universitetet i Oslo).

\section{Litteratur}

Bauman, Z. (1996b): "Postmodernitet, identitet og moral" i A.J. Vetlesen (red.): Narhetsetikk, Ad Notam Gyldendal.

Bauman, Z. (1996a): Postmodern ethics, Blackwell.

Bernstein, R. J. (2003): "Rorty's Inspirational Liberalism” i C. Guignon/D. R. Hiley (red.): Richard Rorty, Cambridge University Press, s. 124-138.

Blackburn, S. (2005): Truth - A Guide, Oxford University Press.

Cavell, M. (2006): Becoming a Subject - Reflections in Philosopby and Psychoanalysis, Oxford University Press.

Connolly, W.E. (2004): "Catholicism and Philosophy: a nontheistic appreciation" i R. Abbey (red.): Charles Taylor, Cambridge University Press, s. 52-83.

Dreyfus, H. L. (2004): “Taylor's (Anti-) Epistemology” i R. Abbey (red.): Charles Taylor, Cambridge University Press, s. 52-83. 
Hellesnes, J. (2002): Grunnane, Universitetforlaget.

Kerr, F. (2004): “The Self and the Good - Taylor's Moral Ontology” i R. Abbey (red.): Charles Taylor, Cambridge University Press, s. 84-104.

Lundestad, E. (2006, af upubl. manuskript): "Del IV: Mennesket som sosialt vesen".

Martin, R./Barresi, J. (2006): The Rise and Fall of Soul and Self: An Intellectual History of Personal Identity, Columbia University Press.

Meyer, S. (2005): Den lille Machiavelli - maktspill til hverdagsbruk, Aschehoug.

Nyeng, F. (2001): "'What is real is what you have to deal with" - den udramatiske uomgjengeligheten i Charles Taylors moralske realisme" i Norsk Filosofisk. Tidsskrift nr. 1-2, s. $51-61$.

Nyeng, F. (2000): "Handlingsrasjonalitet og handlingsforklaring - økonomisk atferdsteori i lys av Charles Taylors moralfilosofi" i Norsk Filosofisk Tidsskrift nr. 1, s. 23-32.

Nyeng, F. (2000): Det autentiske menneske - med Charles Taylors blikk på menneskevitenskap og moral, Fagbokforlaget.

Nyeng, F. (2006): Folelser - i filosofi, vitenskap og dagligliv, Abstrakt Forlag.

Putnam, H. (1992): Realism with a buman face, Harvard University Press.

Shotter, J. (2005): "Inside the Moment of Managing: Wittgenstein and the Everyday Dynamics of Our Expressive-Responsive Activities" i Organization studies vol. 26 nr. 1, s. 113-135.

Smith, N. H. (2004): "Taylor and the Hermeneutic Tradition" i R. Abbey (red.): Charles Taylor, Cambridge University Press, s. 29-51.

Svendsen, L. (1999): Kjedsombetens filosofi, Universitetsforlaget.

Taylor, C. (1998): Autentisitetens etikek, Cappelen Akademisk Forlag.

Taylor, C. (1985a): Philosophical Papers I, Cambridge University Press.

Taylor, C. (1985b): Philosophical Papers II, Cambridge University Press.

Taylor, C. (1989): Sources of the Self, Cambridge University Press.

Wittgenstein, L. (1994): Philosophical Investigations, Blackwell.

Yalom, I. D. (1998): Eksistentiel psykoterapi, Hans Reitzels Forlag. 